UDC 34-056.26(497.11)

Dunja Popivoda, lawyer

\title{
10 YEARS SINCE ADOPTION OF THE UN CONVENTION ON THE RIGHTS OF PERSONS WITH DISABILITIES IN SERBIA*
}

\begin{abstract}
The work starts with an introduction on general informations about rights of persons with disabilities in Serbia, the problems they are facing and the legal framework. The next chapter analyses rights of persons with disabilities in UN Convention on the Rights of Persons with Disabilities and its ratification in Serbian Constitution and laws. The main focus is the concept of accessability and access to the environment. Afterwards, the next chapter deals with Serbian laws for people with disabilities: Constitution, Ratification Law, Law about vocational rehabilitation and employment of persons with disabilities, Law about prevention of discrimination of persons with disabilities. And finally, the last chapter concludes the paper with pointing out the urgentness of creating an environment for all by promoting the rights of those with disabilities, by providing access to justice, accessability for services and normal unobstracted life for everybody, without any form of discrimination.

Key words: rights of persons with disabilities, human rights, antidiscrimination laws, UN convention, access to justice, concept of accessability, access to the environment, rehabilitation, employment
\end{abstract}

\section{INTRODUCTION}

Respect of rights of persons with disabilities is of the vital significance for improving thier position in every society. They are extremly sensitive and

\footnotetext{
${ }^{*}$ Rad primljen 31. 7. 2017. godine.
} 
facing different kinds of problems each day. Prejudices and stereotipes in society are leading to discrimination and marginalization of people with disabilities which affect mostly women who are double marginalized because of their gender identity.

The main issue of those with disabilities have in Serbia are unappropriate life conditions, very high level of unemployment, poverty, social marginalization and isolation, inaccessibility to state authority institutions - health, social and cultural institutions, public transport etc.

Serbia, as a developing country and not a member of European Union, has incorporated the UN Convention on the Rights of Persons with Disabilities through Law about ratification the UN convention on the Rights of Persons with Disabilities in 2009. Serbia has three main laws that concern those with disabilities - Law about ban of discrimination, Law about profesional rehabilitation and employment of persons with disabilities and Law about prevention of discrimination of persons with disabilities. Also, Serbia has several antidiscrimination laws regarding this issue such as Law about planning and constructing, Law about public transport, Labor law, Social protection law, Education law. Serbian governmant also conducted Rules about technical standards of accessibility and Improvement strategy for persons with disabilities, which is one step forward to improving life standard of those with disabilities in the country.

The question about position and rights of persons with disabilities, especially their human rights and observing it through the aspect of disability as a social problem, starts to get full attention with democratic reforms in the Republic of Serbia. According to this, problem of disability is no longer an individual problem but the complex social problem which has to be seen through multisectoral approach, colaboration on all levels of government and its institutions, also by the diffferent organizations in society and by those with disabilities themselves.

In accusations of persons with disabilities to the Municipal Ombudsman we come to a conclusion that the main problems these people have are prejudices and work discrimination and also difficulties in getting social help and other social benefits. So one of the exsisting problems for them is not being able to get adequate informations which is not acceptable in $21^{\text {th }}$ century.

Legislation in Serbia doesnt necessary mean change in everyday life for persons with disabilities. The most important is the use of those laws in practice. State institutions, in their own line of work, have to do everything it takes so that dignity and human rights of those with disabilities are respected. Society has to involve them in all areas of social life. State has to provide the eaqual approach to environment (to all the buildings, public transport, schools, hospitals, informations, education, services... etc.) for persons with disabilities, in the urban as well as in the rural parts of the country. 


\section{PROTECTION OF PERSONS WITH DISABILITIES IN SERBIA}

\section{Rights of people with disabilities in Serbia}

According to Serbian Constitution, as the highest legal act in the country, discrimination is forbidden in any way. Constitution guaranties equal labour rights for all people, especially to women, youth and persons with disabilities who have special protection of their rights while working and adjusted working conditions. Those with disabilities have very high social protection according to different laws in the country.

Rights of persons with disabilities are the subject of the large number of international conventions which our country incorporated and therefore became a part of Serbian legal system. The most important is the UN Convention on the Rights of Persons with Disabitilies ${ }^{1}$ which became part of Serbian legal system by Ratification Law of UN Convention on the Rights of Persons with Disabitilies ${ }^{2}$. Convention regulates, in a general way, rights of persons with disabilities and gives obligation to countries who signed the convention to give the eaqual position and eaqual rights for those with disabilities and to protect them in certain situations. Convention regulates legal steps that countries have to take to fullfil these rights, to upgrade and secure them and to ensure eaqual achievement of human rights and liberties to all the individuals. This way countries would upgrade and respect persons with disabilities and their dignity, which is absolutely neccessary.

With ratification of UN Convention on the Rights of Persons with Disabitilies Serbia has been obligated to provide in every sense independent life and full participation for those with disabilities in all phases of life, to take suitable measures to provide them access to all the buildings, public transport, informations and communications, including information and communication technologies and systems. This has to be done eaqualy in the cities and on the countryside. These measures include identification and removal of the opsticals to approach to roads, buildings, public transport, architectural accessability to state authority buildings, public companies, also benefits in close space and outdoor, including schools, houses, healthcare institutions and working places. ${ }^{3}$

Serbian governmant brought Improvement strategy for persons with disabilities $^{4}$. The goal is to improve the position of those with disabilities up to a

\footnotetext{
${ }^{1}$ UN Convention on the Rights of Persons with Disabitilies, 2006.

${ }^{2}$ Ratification Law of UN Convention on the Rights of Persons with Disabitilies Official Gazette of Republic of Serbia no. 42/2009

${ }^{3}$ The exercise on the rights of persons with disabilities in Autonomous Province of Vojvodina, Research of Provincial Ombudsman, Novi Sad, 2014.

${ }^{4}$ Improvement strategy for persons with disabilities, Official Gazette of Republic of Serbia no. $1 / 2007$.
} 
position of being eaqual citizens who have all the rights and responsabilities. The alarming fact is that strategic plans have not yet been brought even after 7 years in Serbia. Some of the local authorities have local action plans for improving the position of those with disabilities but it is highly questionable what has happened with these plans.

As previosly mentioned, regulations regarding persons with disabilities set high standard but the fact that these regulations have no use in practice contributes to not so well position of those with disabilities in Serbian society. There is an enormus difference between the laws and the practice, which gives uncertain rights to persons with disabilities. ${ }^{5}$

Access to the environment, as a main pre-condition in fullfilment the rights of persons with disabilities in all areas, is not yet in adequate way acchived accross the country. It is different in different parts of the country. In some places, the access for eg. to public authority buildings is available and adequate but in others is not; the access to some of the state, local or other public companies is available but nowhere is available in every state authority institution which is severe problem for those with disabilities. Not being able to access all the buildings makes them discriminated and not respected in their basic human rights. This way, unfortunatelly, the main ideas and goals of the UN Convention are not yet fully achieved in Serbia.

We come to an impression that the concept of accessibility for those with disabilities is not entirely understood in Serbia. Local authorities in the country are trying to get some partial, individual solutions instead the general ones. State has to solve problem with inaccessibility for persons with disabilities on a general level in a way that will be complitely and fully tenable for these people. Their lifes have to be easier with these future solutions or ,as much normal as possible" comparing to other people. They have to be fully included in society.

Research resoults show that educational and healthcare institutions are more approachable then other companies or institutions. The most accessible buildings are schools which organise a special educational programme for children and adults with disabilities and for those who are intelectualy challenged. Here we come to a paradox- schools which have the regular (not special) educational programme do not have adequate access for children with disalibilies and precisely this is the main reason why parents who have children with disabilities enroll them in these ,special schools“ because they are more approachable for their children. This certanly does not contributes achiving the Convention goals and state programme for inclusive education ${ }^{6}$.

\footnotetext{
${ }^{5}$ Research on the rights of persons with disabilities in Autonomous Municipal of Vojvodina Research of the Provincial Ombudsman, Novi Sad, 2015.

${ }^{6}$ Inclusive education is a principe in education when children with anykind of disability or who are intelectually challenged are included in regular (not special) school programmes.This way they are becoming a part of sociaty in everyday life and that gives them a satisfaction to
} 


\section{Serbian laws for people with disabilities}

Serbian Constitution. Constitution is the highest legal act in the country which promotes equality and respect of human rights and liberties as the most valuable democratic principles. It promotes protection on the rights of persons with disabilities. Discrimination is forbidden in every sense- race, gender, sexual orientation, age, ethnicity, birth, religion, social background, political beliefs, culture, language, property status, mental or physical disability.

Ratification Law of Convention on the rights of persons with disabitilies. Serbia has incorporated in national law the UN Convention on the Rights of Persons with Disabilities and its articles became obligated part of Serbian legal system ${ }^{7}$. In practical sense, this means that Serbia has obligation to provide access to public transport, informations, comunications, buildings etc. for persons with disabilities.

Serbian laws that regulate this issue in general way are:

- Law about vocational rehabilitation and employment of persons with disabilities ${ }^{8}$,

- Law about discrimination prevention of persons with disabilities ${ }^{9}$

Serbian laws that regulate this issue in individual and special sense are:

- Law about prevention of discrimination ${ }^{10}$

- Labour Law ${ }^{11}$

- Law about social protection ${ }^{12}$

- Law about basics of education ${ }^{13}$

- Law about planning and construction ${ }^{14}$

- Law about benefits in national transport for persons with disabilities ${ }^{15}$

- Law about public roads ${ }^{16}$

- Law about traffic safety ${ }^{17}$

- Custom law ${ }^{18}$

move forward with their education. However, some problems do appear if the child is seriously disabled in intelectual or physical sense but these problem ought to be solved in future preactice.

${ }^{7}$ Ratification law of Convention on the rights of persons with disabitilies, Official Gazette of Republic of Serbia no. 42/2009.

${ }^{8}$ Official Gazette of Republic of Serbia no. 36/2009 and 32/2013

${ }^{9}$ Official Gazette of Republic of Serbia no. 36/2009 and 32/2013

${ }^{10}$ Official Gazette of Republic of Serbia no. 22/2009.

${ }^{11}$ Official Gazette of Republic of Serbia no. 24/2005, 61/2005, 54/2009, 32/2013.

${ }^{12}$ Official Gazette of Republic of Serbia no. 24/2011.

${ }^{13}$ Official Gazette of Republic of Serbia no. 72/2009, 52/2011, 55/2013.

${ }^{14}$ Official Gazette of Republic of Serbia no. 72/2009, 81/2009, 64/2010, 24/2011, 121/2011, 42/2013, 50/2013, 98/2013.

${ }^{15}$ Official Gazette of Republic of Serbia no. 22/93, 25/93, 101/2005.

${ }^{16}$ Official Gazette of Republic of Serbia no. 101/2005, 123/2007, 101/2011, 93/2012

${ }^{17}$ Official Gazette of Republic of Serbia no. 41/2009, 53/2010, 101/2011, 32/2013

${ }^{18}$ Official Gazette of Republic of Serbia no. 18/2010, 111/2012, 29/2015, 108/2016. 
Law about vocational rehabilitation and employment of persons with disabilities. This law regulates incentives for better employment persons with disabilities and creates their equal participation in labour market, evaluation of their working capacities, vocational rehabilitation, employment obligation of those with disabilities and other questions regarding this matter. According to this law, person with disability has following rihgts: right to establish status and have work capacity assessment, right to employment incentive, social involvment and afirmation of equal possibilities in labour market, right to activities and measures for vocational rehabilitation, right to be employed under general conditions or under special conditions, right to active employment policy measures and all other rights in accordance with the law.

Law about prevention of discrimination of persons with disabilities. This is the first antidiscrimination law in Serbia. It regulates regime of prevention of discrimination on the basis of disability, special cases of discrimination of persons with disabilities, the procedure of protection those who are exposed to any form of discrimination, incentives for improvement of their equality and social inclusion in society. Discrimination of those with disabilities is strictly forbidden in Serbian law. Discrimination on the basis of disability for example: if the service is offered in different way or with unfavorable conditions to persons with disabilities, if service is not allowed to persons with disabilities etc is strictly forbidden.

By accepting the concept of inclusion alltogether with antidiscrination laws, especially Law about vocational rehabilitation and employment of persons with disabilities, it is set the legal basis for eaquation of those with disabilities and their employment and education.

The concept „Design for everybody“ represents the start of creating an environment for all and by that it means the accessibility to environment, services and goods regarding the capability, age or any other differencies between people.

\section{CONCLUSION}

For fully and complitely inclusion of persons with disabilities in everyday life it is neccessary to provide equal possibilities for employment and education. By accepting the principle of inclusive education in Serbia and with other antidiscrimination laws, the legal basic for equation in education and employment for those with disabilities is set. However, the environment in Serbia is still inaccessible. Therefore, the concept of accessability through the concept of „Design for everybody“ is neccessary for further integration of persons with di- 
sabilities in Serbian society. ${ }^{19}$ The concept „Design for everybody“ represents a principle for creating an environment for all. That means the accessibility for services and products no matter the capabilities, age, gender or any other difference between people. The most important is to provide normal and unobstracted life for disabled persons, without any form of discrimination ${ }^{20}$.

State authority in Serbia has to conduct strategic documents for promotion the rights of those with disabilities so that local authorities can provide adequate measures and steps for implementation of all the regulations conserning this social problem. Most of the attempts in regulating this issue are used for social protection of those with disabilities.

Local authorities mostly support different organisations who protect persons with disabilities through financial support and donations. This kind of support depends on capacity of local authority on one side, and on the other, direct support of local goverment improves the position of those with disabilities through sistematic use of laws.

State has to set up a fundation for support programms for those with disabilities and to conduct policy to improve their position. Also, every local authority has to have a service that will provide organise support and help for those with disabilities. Accessability to the environment is crucial for persons with disabilities bacause by being able to move everywhere without problems makes their life easier and bearable. We get to an impression that the concept of inclusion is not properly understood by local govermants in Serbia because they are trying to solve this problem individualy and separatly. On the contrary, this problem has to be solved entirely and eaqualy in all parts of the country. This is the only acceptable and sustainable way. The research resoults show that schools and other educational buildings are more accessible than others. The best access have schools with special inclusive educational programme for those with disabilities.

Less than half of all local authorities in the country have strategic documents which regulate the rights of persons with disabilities. These documents are mostly about social problems of those with disabilities but there is no confirmation that strategic plans nor other legal acts regulate this problem in other parts of the country. Only some of the cities such as Belgrade and Novi Sad have starategies and action plans how to solve accessability problem for persons with disabilities. Most of the municipals and cities do not have expert bodies or persons solely responsible for questions regading those with disabilities. Local authorities are only trying to conduct certain action plans in education

${ }^{19}$ Pešid Vladimir: European Union and persons with disabilities, Friedrich Ebert Stiftung and State Office of the President, Beograd, 2006.

${ }^{20} \mathrm{http}$ ://www.crid.org.rs/dizajn-za-sve/ seen on the $15^{\text {th }}$ of April 2017. 
and to organise daily centres for children with disabilities or help in the house services.

Public transport is very important for those with disabilities. Unfortunatelly, in Serbia, this remains a problem. Bus and train stations remain inaccessable for those with disabilities. Only very small number of buses ${ }^{21}$ have access for persons with disabilities; no bus stops is adequate for those with disabilities. Taxis as well remain inaccessable.

Similar situation is in educational, cultural and healthcare institutions. The access in schools is complitely suitable for those with disabilities but in cultural and healthcare institutions is not. There is no access inside the buildings or to all the floors. There is no access to toilets, inside the buildings or to public toilets for those with disabilities. One of the municipals in Serbia has an interesting solution where the local library offers house delivery of books to persons with disabilities.

Local authorities in Serbia have large number of problems in their work because they have no financial support for their projects when it comes to persons with disabilities. Those with disabilities are facing slow system, birocratcy, lack of information, inaccessability, unsufficient involvement of experts, lack of professional comunication and colaboration, lack of transparency, lack of conditions for realization of delegated jurisdictions in the field of social care from state level to local authorities.

In the 10 years since the adoption of the UN Convention on the Rights of Persons with Disabilities, Serbia has adequate laws and legal protection for those with disabilities but still has to continue to work on improving access to justice for those with disabilities. This goal has not yet been achieved in it's full potential but Serbia is going in a right direction and with adequate financial support access to justice for those with disabilities will be fully acomplished in the future.

\section{BIBLIOGRAPHY}

\section{Conventions and Laws}

Convention on the Rights of Persons with Disabitilies, United Nations, 2006.

Ratification Law of the UN Convention on the Rights of Persons with Disabitilies, Official Gazette of Republic of Serbia no. 42/2009

Law about vocational rehabilitation and employment of persons with disabilities, Official Gazette of Republic of Serbia no. 36/2009 and 32/2013

Law about discrimination prevention of persons with disabilities, Official Gazette of Republic of Serbia no. 36/2009 and 32/2013

\footnotetext{
${ }^{21}$ In the city of Novi Sad only $8,3 \%$ buses are accessible for those with disabilities.
} 
Law about prevention of discrimination, Official Gazette of Republic of Serbia no. $22 / 2009$.

Labour Law, Official Gazette of Republic of Serbia no. 24/2005, 61/2005, 54/2009, $32 / 2013$.

Law about social protection, Official Gazette of Republic of Serbia no. 24/2011.

Law about basics of education, Official Gazette of Republic of Serbia no. 72/2009, $52 / 2011,55 / 2013$.

Law about planning and construction, Official Gazette of Republic of Serbia no. 72/2009, 81/2009, 64/2010, 24/2011, 121/2011, 42/2013, 50/2013, 98/2013.

Law about benefits in national transport for persons with disabilities, Official Gazette of Republic of Serbia no. 22/93, 25/93, 101/2005.

Law about public roads, Official Gazette of Republic of Serbia no. 101/2005, 123/2007, 101/2011, 93/2012.

Law about traffic safety, Official Gazette of Republic of Serbia no. 41/2009, 53/2010, $101 / 2011,32 / 2013$.

Custom law, Official Gazette of Republic of Serbia no. 18/2010, 111/2012, 29/2015, $108 / 2016$.

Improvement strategy for persons with disabilities, Official Gazette of Republic of Serbia no. 1/2007.

\section{Books and articles}

The exercise on the rights of persons with disabilities in Autonomous Province of Vojvodina, Research of Provincial Ombudsman, Novi Sad, 2014.

Research on the rights of persons with disabilities in Autonomous Municipal of Vojvodina, Research of the Provincial Ombudsman, Novi Sad, 2015.

Pešid Vladimir: European Union and persons with disabilities, Friedrich Ebert Stiftung and State Office of the President, Belgrade, 2006.

\section{Web sources}

http://www.crid.org.rs/dizajn-za-sve/ seen on the $15^{\text {th }}$ of April 2017. 